\title{
Psychological Career Resources, Career Adaptability and Hardiness in Relation to Job Embeddedness and Organizational Commitment
}

\author{
Nadia Ferreira \\ Melinde Coetzee \\ Andries Masenge \\ University of South Africa
}

Correspondence to be directed to Dr Nadia Ferreira Department of Human Resource Management, University of South Africa, PO Box 392, University of South Africa, Pretoria, South Africa 0003, E-mail: ferren@unisa.ac.za

The study examined the relationship between employees' psychological career meta-capacities and their job retention-related dispositions. Participants were a convenience sample $(n=355)$ of managerial and staff levels in the human resource management field. They completed the Psychological Career Resources Inventory (PCRI), Career Adaptability Inventory (CAI), Personal Views Survey II (PVS), Job Embeddedness Scale (JES) and the Organizational Commitment Survey (OCS). Data were analyzed using canonical correlations to predict the relationship between the psychological career meta-competencies and the job retention-related dispositions. Structural Equation Modelling was used to validate the overall relationship between the two canonical construct variates. The results show that the psychological career meta-capacities predict the job retention-related factor job embeddedness.

Keywords: psychological career meta-capacities, career resources, adaptability, hardiness, dispositions, job embeddedness, organizational commitment

The retention of qualified, highly skilled and high performing employees is important for businesses competiveness (Hausknecht, Rodda, \& Howard, 2009; Presti, Nonnis, \& Briscoe, 2011; Rappaport, Bancroft, \& Okum, 2003; Samuel \& Chipunza, 2009). Organizations that do not manage to retain their high performers will be left with an understaffed and less qualified workforce that will ultimately hold back their capability to continue being competitive (Presti et al., 2011).

The retention of employees is influenced by their job embeddedness and commitment to the organization (Joâo, 2011; Van Dyk, 2012). It is also influenced by psychological coping resources and self-regulation capacities that include individuals' ability to adapt to and deal proactively with the changing and uncertain nature of their careers in the contemporary world of work (Bezuidenhout, 2010; Ferreira, 2009; Savickas, 2011; Savickas et al., 2009; Savickas \& Porfeli, 2012). However, in an increasingly turbulent job environment context people are increasingly dependent on their psychological and social resources (human capital), and less dependent on organizational career arrangements (Savickas, 2011). This may be because they experience more frequent career transitions, have greater agency in career decisions and must be able, adaptable life-long learners (Arthur, Khapova, \& Wilderom, 2005; Baruch, 2004; Rossier, Zecca, Stauffer, Maggiori, \& Dauwalder, 2012; Savickas, 2011; Savickas \& Porfeli, 2012). Consequently, subjective career resources that emphasize psychological attributes may be increasingly important to work participation in today's work environment (Brown, George-Curran, \& Smith, 2003; Coetzee, 2008; Ebberwein, Krieshok, Ulven, \& Prosser, 2004; Kidd, 2008; Savickas, 2011; Savickas et al., 2009; Savickas \& Porfeli, 2012; Van Dam, 2004).

In the current study we examined how individuals' psychological career meta-capacities (comprising their psychological career resources, career adaptability resources and hardiness) relate to their retention-related dispositions (job embeddedness and organizational commitment). Specifically, we propose that individuals' repertoire of psychological career resources, career adaptability resources, and hardiness are explained by his or her retention-related dispositions (job embeddedness and organizational commitment) by acting as mediating constructs between an individual's work and personal life.

\section{Psychological Career Meta-Capacities}

Psychological career meta-capacities act as personal resources in managing the person-environment fit harmonics. For instance, psychological career resources (people's career preferences and values, career enablers, career drivers and career harmonizers) enable individuals to adapt to changing career circumstances and to shape and select environments in order to attain success within a particular socio-cultural context (Coetzee, 2008).

People's career preferences and values comprise their unique views about the paths their careers should follow and guide their career decisions. Together with people's sense of career purpose, career directedness and career venturing attitudes. For instance, career enablers (practical or creative skills, and personal and interpersonal management skills that help people to succeed in their careers), career harmonizers (people's self-esteem, behavioral adaptability, emotional literacy and social connectivity) are psychological attributes important to job retention (Coetzee, 2008).

Savickas's $(1997,2005)$ proposed the notion of career adaptability to refer to a set of five specific attitudes, beliefs, and competencies (concern, control, curiosity, confidence and commitment), which shape the actual problem-solving strategies and coping behavior that individuals use to synthesize their vocational self-concepts with work roles. 
As a psychological career resource, hardiness is regarded as a collection of personality attributes related to commitment, control and challenge. Individuals high in hardiness tend to whole-heartedly involve themselves in or commit to whatever they are doing, believe and act as if they can influence or control the events forming their lives, and consider change to be not only normal but also a stimulus or challenge to development or personal growth (Azeem, 2010; Delahaij, Gailard, \& van Dam, 2010; Hystad, Eid, Johnsen, Laberg, \& Bartone, 2010; Kobasa, Maddi, \& Zola, 1985; Zhang, 2010).

\section{Retention-Related Dispositions}

Job embeddedness and organizational commitment are regarded as a composite set of retention-related dispositions. Job embeddedness refers to indviduals' dispositional orientations or perceptions of their: (1) fit (the extent to which a person perceives that the job, organization and environment meshes with or complements (fit) other areas and aspects of his or her life space), (2) links (the extent of an individual's ties with other people and activities at work to family, non-work and off-the-job interests), and (3) sacrifice (the ease with which a person feel that links can be broken, or people's perceptions of what they would have to give up if they were to leave their current position (Feldman \& Ng, 2007). In short, the more an employee perceives that which he or she would have to give up (financially or psychologically) by leaving a job or organization, the more difficult it will be for the individual to sever employment with the organization (Mitchell et al., 2001; Shaw, Delery, Jenkins, \& Gupta, 1998).

Organizational commitment reflects three extensive aspects of reasons for staying at or leaving an organization, namely: (1) affective commitment, (2) continuance commitment, and (3) normative commitment. Commitment is viewed as a set of affect-driven job attitudes that reflect the individual's affective or psychological attachment to, identification with and participation in the organization; acknowledgement of the consequences of, or expenses and threats linked to leaving the organization (and thus their continuance commitment based on their perception that they need to stay); and an internalized normative idea of ethical responsibility to stay which allows individuals to value their continued membership of a specific organization (Allen \& Meyer, 1990). Similar to job embeddedness, research indicates organizational commitment as a significant predictor of turnover and job satisfaction (Griffeth, Hom, \& Gaertner, 2000; Hom \& Griffeth, 1995; Mitchell et al., 2001).

\section{Goals of the Study}

We hypothesize that highly career adaptable individuals with a range of well-developed career resources might show stronger perceptions of embeddedness (fit) with the organization, having a sense that their values, career goals and plans for the future fit with the larger corporate culture as well as the demands (e.g., job knowledge, skills and abilities) of the immediate job (Mitchell et al., 2001). Research by Van Dyk (2012) also produced evidence that high levels of job embeddedness significantly increase individuals' sense of organizational commitment.

We also propose that individuals with a well-developed hardy personality might demonstrate the hardy values of cooperation, credibility and creativity at team and organizational level, implying higher levels of job embeddedness and organizational commitment.

\section{Method}

\section{Sample and Procedure}

The participants were a non-probability sample $(\mathrm{N}=355)$ of employed adults at managerial and staff levels in a South African service industry who were enrolled for a human resource management programme at a distance higher education institution. Data were collected during a study school which the participants attended. The sample predominantly comprised blacks $(92 \%)$ and females (71\%), and single (55\%) and married (38\%) participants mostly in the early adulthood life stage or the establishment phases of their careers (26 - 40 years; $64 \%)$ as indicated in Table 1 . In terms of employment $76 \%$ of the participants were full time employed.

\section{Measures}

Participants completed the Psychological Career Resources Inventory (PCRI), the Career Adaptability Inventory (CAI), the Personal Views Survey II (PVS-II), the Job Embeddedness Scale (JES) and the Organizational Commitment Survey (OCS). They also provided data on personal demographics.

The Psychological Career Resources Inventory (PCRI: Coetzee, 2008) is a self-rated measure of career preferences, career values, career enablers, career drivers, and career harmonizers. It is scored on a 6-point Likert-type scale (1= never, 6 = always). The Cronbach alpha inter-consistency coefficients with the study sample were .71 to .88 .

The Career Adapt-Abilities Inventory (CAI: Savickas, 2010) is 55 item self-report measure of concern, control, curiosity, cooperation and confidence. It is scored on a 5-point Likert-type scale ( 1 = strongest, 5 = not strong). The Cronbach's alpha coefficients (internal consistency) for the five subscales for the study sample were as follows: concern (.88), control (.90), curiosity (.90), cooperation (.85) and confidence (.90).

The Personal Views Survey II (PVS-II: CITATION) is a 50 item self-rated measure of hardi-commitment, control and challenge and scores on a 4-point Likert-type (1=not at all true, 4 completely true. The Cronbach alpha coefficients (internal consistency) for the five subscales for the sample of this study were as follows: commitment (.76), control (.71) and challenge (.59)

The Job Embeddedness Scale (JES: Mitchell, Holtom \& Lee, 2001) is a 23 item measure of organizational fit (7 items), sacrifice (10 items) and links (6 items). It is scored on a 6-point Likert type scale ( 1 = strongly disagree, 6 = strongly agree). The Cronbach alpha coefficients (internal consistency) for the five subscales (as obtained for the sample of this study) were as follows: fit (.84), links (.77) and sacrifice (.87).

The Organizational Commitment Scale (OCS: Meyer \& Allen, 1997) is a 30 item Likert scale measure $(1=$ strongly disagree, 7 = strongly agree) of affective commitment (8 items), continuance commitment ( 9 items) and normative commitment (6 items). The Cronbach Alpha coefficients (internal consistency) for the five subscales (as obtained for the sample of this study) were as follows: affective commitment (.56), continuance commitment (.73) and normative commitment (.74).

\section{Data Analyses}

Canonical correlational analyses were performed to assess the relationship between the PCRI, CAI and PVS II variables (as a composite set of multiple independent variables of the psychological career meta-capacities construct), and the JES and OCS variables (as a composite set of multiple dependent variables of the retention-related dispositions construct). Canonical 
Table 1

Summary of Frequency Distribution: Biographical Profile of Sample

\begin{tabular}{|c|c|c|c|c|c|}
\hline & & Frequency & $\%$ & $\begin{array}{l}\text { Valid } \\
\%\end{array}$ & $\begin{array}{c}\text { Cumulative } \\
\%\end{array}$ \\
\hline \multirow[t]{3}{*}{ Gender } & Males & 103 & 29.0 & 29.0 & 29.0 \\
\hline & Females & 252 & 71.0 & 71.0 & 100.0 \\
\hline & Total & 355 & 100.0 & 10.0 & \\
\hline \multirow[t]{6}{*}{ Race } & African & 303 & 85.4 & 85.4 & 85.4 \\
\hline & Coloured & 19 & 5.4 & 5.4 & 9.7 \\
\hline & Indian & 5 & 1.4 & 1.4 & 92.1 \\
\hline & White & 26 & 7.3 & 7.3 & 99.4 \\
\hline & Other & 2 & .6 & .6 & 100.0 \\
\hline & Total & 355 & 100.0 & 10.0 & \\
\hline \multirow[t]{5}{*}{ Age } & 25 and younger & 48 & 13.5 & 13.5 & 13.5 \\
\hline & $26-40$ years & 227 & 63.9 & 63.9 & 77.5 \\
\hline & $41-55$ years & 76 & 21.4 & 21.4 & 98.9 \\
\hline & 56 and older & 4 & 1.1 & 1.1 & 100.0 \\
\hline & Total & 355 & 100.0 & 100.0 & \\
\hline \multirow[t]{5}{*}{ Marital status } & Single & 194 & 54.6 & 54.6 & 54.6 \\
\hline & Married & 134 & 37.7 & 37.7 & 92.4 \\
\hline & Widowed & 5 & 1.4 & 1.4 & 93.8 \\
\hline & Separated/divorced & 22 & 6.2 & 6.2 & 100.0 \\
\hline & Total & 355 & 100.0 & 100.0 & \\
\hline \multirow[t]{6}{*}{ Employment status } & School/graduate & 17 & 4.8 & 4.8 & 4.8 \\
\hline & Unemployed & 34 & 9.6 & 9.6 & 14.4 \\
\hline & Part-time employed & 30 & 8.5 & 8.5 & 22.8 \\
\hline & Full-time employed & 270 & 76.1 & 76.1 & 98.9 \\
\hline & Self-employed & 4 & 1.1 & 1.1 & 100.0 \\
\hline & Total & 355 & 100.0 & 100.0 & \\
\hline
\end{tabular}

Note. $\mathrm{N}=355$

correlation analysis limits the probability of committing Type I errors (Hair, Black, Babin \& Anderson, 2010). The Wilks Lambda's chi-square test was performed to test for the significance of the overall canonical correlation between the independent and dependent variates of a canonical function. In order to counter the probability of a type I error, it was decided to set the significance value for interpreting the results at a $95 \%$ confidence interval level (F $p=.05)$.

Effect sizes were used to decide on the practical significance of the canonical correlation findings. In line with guidelines by Hair et al. (2010), the cut-off criteria for factorial loadings $(=.30)$ were used to interpret the relative importance of the canonical structure correlations or loadings in deriving the canonical variate constructs. The redundancy index was also considered for assessing the magnitude of the overall correlational relationships between the two variates of a canonical function and the practical significance of the predictive ability of the canonical relationship (Hair et al., 2010). Squared canonical correlation $\left(R c^{2}\right)$ values of $=.12$ (small practical effect), $=.13=.25$ (medium practical effect) and $=.26$ (large practical effect) $(F p=$ .05) (Cohen, 1992) were also considered in the interpretation of the magnitude or practical significance of the results.

Structural Equation Modelling (SEM) was also performed using AMOS 18 (Arbuckle, 1995-2009) to validate the overall relationship between the two canonical construct variates (psychological career attributes and retention-related dispositions) as latent variables. The canonical correlation analysis results were regarded as the measurement model. In line with guidelines provided by Garson (2008), we assumed that an adequate fit of the structural model to the measurement data exists when we obtain a confirmatory fit index (CFI) of .90 or higher, a root-mean-square error of approximation (RMSEA) of .08 or lower, and a standardized root-mean-square residual (SRMR) of .05 or lower.

\section{Results}

\section{Descriptive Statistics: Means and Standard Deviations}

Table 2 shows that the participants obtained the highest mean scores on the following PCRI subscales: stability/expertise career preference $(M=5.28 ; S D=.11)$; growth/development career value $(M=5.42 ; S D=.116)$; career purpose driver $(M=5.39 ; S D=.05)$; and self/other skills $(M=4.89 ; S D=.23)$.

Table 2 also shows that the participants obtained the highest mean scores on the CAI (career adaptability) control $(M=$ 4.39; $S D=6.93)$, PVS-II (hardiness) challenge $(M=3.43 ; S D=$ $5.71)$, JES fit $(M=5.04 ; S D=6.73)$ and OCS continuance commitment $(M=4.76 ; S D=9.92)$ subscales. 
Table 2

Descriptive Statistics: Means, Standard Deviations and Reliability Summary Statistics (PCRI, CAAS, PVS-II, JES and OCS)

\begin{tabular}{|c|c|c|}
\hline Scale dimension & $M(S D)$ & $\alpha$ \\
\hline \multicolumn{3}{|c|}{ PCRI (psychological career resources) } \\
\hline Career preference & $4.89(10.92)$ & .86 \\
\hline Stability/Expertise & $5.28(.11)$ & .74 \\
\hline Managerial & $4.78(.94)$ & .75 \\
\hline Variety/Creativity & $4.95(.84)$ & .72 \\
\hline Independence/Autonomy & $4.32(.39)$ & .74 \\
\hline Career values & $5.13(3.87)$ & .85 \\
\hline Growth/Development & $5.42(.16)$ & .74 \\
\hline Authority/Influence & $4.84(.68)$ & .64 \\
\hline Career enablers & $4.70(6.40)$ & .83 \\
\hline Practical/Creative skills & $4.47(.29)$ & .70 \\
\hline Self/Other skills & $4.89(.23)$ & .79 \\
\hline Career drivers & $4.95(7.00)$ & .85 \\
\hline Career purpose & $5.39(.05)$ & .83 \\
\hline Career directedness & $4.69(.79)$ & .81 \\
\hline Career venturing & $4.75(.84)$ & .71 \\
\hline Career harmonizers & $4.68(13.36)$ & .89 \\
\hline Self-esteem & $5.09(.10)$ & .82 \\
\hline Behavioral adaptability & $4.66(.28)$ & .81 \\
\hline Emotional literacy & $4.22(.14)$ & .71 \\
\hline Social connectivity & $4.75(.34)$ & .74 \\
\hline \multicolumn{3}{|l|}{ CAI (career adaptability) } \\
\hline Concern & $4.12(6.79)$ & .88 \\
\hline Control & $1.39(6.93)$ & .90 \\
\hline Curiosity & $4.16(7.08)$ & .90 \\
\hline Cooperation & $4.05(7.21)$ & .85 \\
\hline Confidence & $4.21(6.88)$ & .90 \\
\hline \multicolumn{3}{|l|}{ PVS-II (hardiness) } \\
\hline Commitment & $2.31(6.46)$ & .76 \\
\hline Control & $2.59(6.47)$ & .71 \\
\hline Challenge & $3.43(5.71)$ & .59 \\
\hline \multicolumn{3}{|l|}{ JES (job embeddedness) } \\
\hline Fit & $5.04(6.73)$ & .84 \\
\hline Links & $4.68(6.48)$ & .77 \\
\hline Sacrifice & $4.68(10.94)$ & .87 \\
\hline \multicolumn{3}{|c|}{ OCS (organizational commitment) } \\
\hline Affective commitment & $4.71(7.28)$ & .56 \\
\hline Continuance commitment & $4.76(9.92)$ & .73 \\
\hline Normative commitment & $4.70(7.55)$ & .74 \\
\hline
\end{tabular}

Note. $\mathrm{N}=355$

\section{Psychological Career Meta-Capacities, Job Embeddedness and Organizational Commitment}

Table 3 shows that the canonical model has three canonical functions (dimensions) of which the canonical correlation of only the first function is statistically significant: $\mathrm{Rc}=0.454\left(R c^{2}=.21\right.$; moderate practical effect; $\mathrm{F}(p)=1.56(p=.0001)$. The canonical function explains the relationship between the two canonical variates, that is, the canonical variate for the set of dependent variables (retention-related dispositions: job embeddedness and organizational commitment) and the canonical variate for the set of independent variables (psychological career attrib- utes: psychological career resources, career adaptability and hardiness). The four multivariate criteria and the $\mathrm{F}$ approximations for the model are also statistically significant $(p=.0001)$

Table 4 shows that the psychological career meta-capacities variate construct was most strongly influenced by the PCRI (psychological career resources) and CAI (career adaptability) variables. More specifically, the PCRI variables career directedness $(R c=.59)$, self/other skills $(R c=.56)$ and behavioral adaptability $(R c=.52)$ showed a practically large degree of association with the psychological career meta-capacities construct variate. The PCRI career preference variable stability/ex- 
Table 3

Canonical correlation Analysis Relating to Psychological Career Resources, Career Adaptability and Hardiness (Independent Variables) to Job Embeddedness and Organizational Commitment (Dependent Variables)

Measures of overall model fit for canonical correlation analysis

\begin{tabular}{|c|c|c|c|c|}
\hline $\begin{array}{l}\text { Canonical } \\
\text { function }\end{array}$ & $\begin{array}{c}\text { Overall } \\
\text { Canonical } \\
\text { correlation }(\mathrm{Rc})\end{array}$ & $\begin{array}{c}\text { Overall } \\
\text { squared canonical } \\
\text { correlation }\left(\mathrm{Rc}^{2}\right)\end{array}$ & F Statistics & Probability $(p)$ \\
\hline 1 & .454 & .21 & 1.56 & $.0001^{\star *}$ \\
\hline 2 & .370 & .13 & 1.22 & .06 \\
\hline 3 & .283 & .08 & 1.01 & .46 \\
\hline 4 & .271 & .07 & .94 & .60 \\
\hline 5 & .224 & .05 & .81 & .79 \\
\hline 6 & .120 & .04 & .75 & .76 \\
\hline
\end{tabular}

Multivariate Tests of Significance

\begin{tabular}{lccc} 
Statistics & Value & Approximate F-Statistic & Probability $(p)$ \\
\hline Wilks' lambda & .535 & 1.56 & $<.0001^{* \star *}$ \\
Pillai's trace & .583 & 1.54 & $<.0001^{\star * *}$ \\
Hotelling-Lawley trace & .675 & 1.58 & $<.0001^{\star * *}$ \\
Roy's Greatest Root & .259 & 3.72 & $<.0001^{* * *}$ \\
\hline
\end{tabular}

Note. ${ }^{* * *} p \leq .001 ; \mathrm{N}=355$

pertise $(R c=.36)$, and the career harmonizer variables self-esteem $(R c=.42)$ and social connectivity $(R c=.42)$ showed a practically moderate degree of association with the psychological career meta-capacities construct variate $\left(R c^{2}=\right.$ $13=.25$ ). All the CAI (career adaptability) variables showed a practically large degree of association with the psychological career meta-capacities construct variate $\left(R c^{2}=26\right)$ except for cooperation $\left(R c=.48 ; R c^{2}=23 \%\right)$ that showed a moderate degree of association with the psychologival career meta-capacities construct variate. All the PVS-II (hardiness) commitment $(R c=-.64)$, control $(R c=-.49)$ and challenge $(R c=-.31)$ variables showed an inverse association of a practically moderate degree with the psychological career meta-capacities construct variate.

Table 4 shows that the retention-related dispositions canonical variate construct was most strongly influenced by the JES-fit variable ( $R c=.77$; very large practical effect), and to a lesser extent by the JES variables links $(R c=.43$; moderate practical effect) and sacrifice ( $R c=.38$; small practical effect). The results furthermore indicated that the retention-related dispositions variate construct was most strongly influenced by the OCS continuance variable $(R c=-.49)$, which indicated an inverse association of a practically moderate degree with the retention-related dispositions variate construct. The OCS affective $(R c=-.08)$ and normative variables $(R c=.07)$ both indicated an association with the canonical variate construct of small practical effect.

Career meta-capacities. The psychological career meta-capacities canonical variate construct was able to predict only $4 \%$ (small practical effect) of the variance in the individual original retention-related dispositions construct variables. The retention-related dispositions canonical variate construct was able to predict only $4 \%$ (very small practical effect) of the variance in the individual original PCRI, CAI and PVS-II variables. Neither of the two ca- nonical variate constructs was thus found to be a good overall predictor of the opposite canonical variate construct. By contrast, each canonical variate was a stronger predictor of its own construct variables. The psychological career meta-capacities canonical variate construct explained 19\% (moderate practical effect) of the variance in the individual original PCRI, CAI and PVS-II variables while the retention-related dispositions canonical variate construct explained $20 \%$ (moderate practical effect) of the variance in the individual original JES and OCS variables.

Job embeddeness. The JES-fit variable exhibited the highest correlation with the psychological career meta-capacities canonical variate construct which explained $21 \%$ of the variance in the JES-fit variable. Overall, it appears from the cross-loadings (although small in practical effect size) that the psychological career meta-capacities of self/other skills, and career adaptability competencies of concern, control, and confidence contributed the most in explaining the variance in the job embeddedness fit variable.

Path analytic structure of career meta-capacities and job embeddedness. Table 5 shows that model 3 had a very good fit to the data: chi-square $=91.24(41 d f) ; \mathrm{CMIN} / d f=2.23$; $p=.000 ; \mathrm{RFI}=.95 ; \mathrm{TLI}=.97 ; \mathrm{CFI}=.98 ; \mathrm{RMSEA}=.06$ and $\mathrm{SRMR}=.03$. Figure 1 specifies the standardized path coefficient estimates between the psychological career meta-capacities construct and its variables and the standardized path coefficients estimates between the retention-related dispositions construct and its variable job embededness (fit). The standardized path coefficient estimates between the psychological career meta-capacities construct and the job embeddedness (fit) construct are also specified.

The model fit (shown in figure 1) revealed that the model explains $9 \%$ of the variance in the retention-related disposition construct fit (job embeddedness). In terms of relative importance, the psychological career meta-capacities construct is 
Table 4

Standardized Canonical Correlation Analysis Results for the First Canonical Function Variates

\begin{tabular}{|c|c|c|c|}
\hline Variate/variable & $\begin{array}{l}\text { Canonical coefficients } \\
\text { (weights) }\end{array}$ & $\begin{array}{l}\text { Canonical loading (Rc) } \\
\text { (structure coefficients) }\end{array}$ & $\begin{array}{c}\text { Canonica } \\
\text { cross-loadings } \\
\text { (squared multiple correlations) }\end{array}$ \\
\hline \multicolumn{4}{|l|}{ Career Preference(PCRI) } \\
\hline Stability/Expertise & .23 & .36 & .16 \\
\hline Managerial & .13 & .23 & .12 \\
\hline Variety/Creativity & -.09 & .32 & .14 \\
\hline Independence/Autonomy & -.24 & -.02 & -.01 \\
\hline \multicolumn{4}{|l|}{ Career Values (PCRI) } \\
\hline Growth/Development & -.09 & .26 & .12 \\
\hline Authority/Influence & -.30 & .01 & .01 \\
\hline \multicolumn{4}{|l|}{ Career Enablers (PCRI) } \\
\hline Practical/Creative skills & .16 & .35 & .16 \\
\hline Self/Other skills & .32 & .56 & .26 \\
\hline \multicolumn{4}{|l|}{ Career Drivers (PCRI) } \\
\hline Career Purpose & -.45 & .25 & .12 \\
\hline Career Directedness & .32 & .59 & .27 \\
\hline Career Venturing & .01 & .32 & .14 \\
\hline \multicolumn{4}{|l|}{ Career Harmonizers (PCRI) } \\
\hline Self-esteem & .16 & .42 & .19 \\
\hline Behavioral adaptability & .03 & .52 & .24 \\
\hline Emotional literacy & .04 & .31 & .14 \\
\hline Social connectivity & -.05 & .42 & .19 \\
\hline \multicolumn{4}{|l|}{ Career adaptability(CAI) } \\
\hline Concern & .18 & .60 & .27 \\
\hline Control & .20 & .60 & .27 \\
\hline Curiosity & -.01 & .53 & .24 \\
\hline Cooperation & .12 & .48 & .22 \\
\hline Confidence & -.09 & .53 & .24 \\
\hline \multicolumn{4}{|l|}{ Hardiness (PVA-II) } \\
\hline Commitment & -.50 & -.64 & -.29 \\
\hline Control & .01 & -.49 & -.22 \\
\hline Challenge & -.00 & -.31 & -.14 \\
\hline \multicolumn{4}{|c|}{ Independent canonical variate (psychological career meta-capacities) } \\
\hline \multicolumn{4}{|l|}{$\begin{array}{l}\text { Overal Rc } c^{2}: .21++ \\
\text { Redundancy index: } 0.4+\end{array}$} \\
\hline Fit & .87 & $.77(.59)$ & .35 \\
\hline Links (organization) & -.10 & $.43(.19)$ & .20 \\
\hline Sacrifice & .10 & $.38(.14)$ & .17 \\
\hline \multicolumn{4}{|c|}{ Organizational commitment (OCS) } \\
\hline Affective commitment & -.12 & $-.08(.01)$ & -.04 \\
\hline Continuance commitment & -.65 & $-.49(.24)$ & -.22 \\
\hline Normative commitment & .15 & $.07(.01)$ & .03 \\
\hline \multicolumn{4}{|c|}{ Dependent canonical variate (Retention-related dispositions) } \\
\hline $\begin{array}{l}\text { Shared variance: } .20++ \\
\text { Overall } R c^{2}: .21++ \\
\text { Redundancy index: } 0.4+\end{array}$ & & & \\
\hline
\end{tabular}

Note. $+R c^{2} \leq .12$ (small practical effect size) $++R c^{2} \geq .13 . \leq 25$ (moderate practical effect size) $+++R c^{2} \geq .26$ (large practical effect size); $\mathrm{N}=355$ 
Table 5

SEM Fit Statistics Summary

\begin{tabular}{lrrrrrrrrrrr}
\hline Model & CMIN $\left(\chi^{2}\right)$ & $d f$ & CMIN/df & $P$ & NFI & RFI & TLI & CFI & RMSEA & SRMR & $\Delta C M I N$ \\
\hline 1 & 12188.97 & 7122 & 1.71 & .00 & .54 & .52 & .73 & .74 & .05 & \\
2 & 155.37 & 60 & 2.59 & .00 & .94 & .91 & .94 & .96 & .07 & 12033.60 \\
3 & 91.24 & 41 & 2.23 & .00 & .96 & .95 & .97 & .98 & .06 & .03 & 64.13 \\
\hline
\end{tabular}

Note: ${ }^{*} p<.01$. Model 1 is the hypothesised five-factor model in which psychological career resources, career adaptability, hardiness, job embeddedness and organizational commitment each load onto their respective latent factors. Model 2 is a two-factor model in which psychological career resources, career adaptability and hardiness load onto one factor and job embeddedness and organizational commitment onto another factor. Model 3 is a two-factor model in which psychological career resources, career adaptability and hardiness load onto one factor (psychological career meta-capacities) and job embeddedness onto a second factor (retention-related dispositions). $\mathrm{CMIN}\left(\div^{2}\right)=$ chi-square; $\mathrm{df}=$ degrees of freedom; $p=$ significance level; NFI = Bentler-Bonett normed fit index; $\mathrm{RFI}=$ relative fit index; $\mathrm{TLI}=$ non-normed fit index; $\mathrm{CFI}=$ comparative fit index; $\mathrm{RMSEA}=$ root-mean-square error of approximation. SRMR = standardized root-mean-square residual; $\mathrm{N}=355$

mostly explained by the psychological career resources variables (self/other skills, behavioral adaptability and career directedness), and the career adaptability variables (curiosity, concern, control, confidence and cooperation). The psychological career resources variables in the model explain $98 \%$ of the variance in the psychological career meta-capacities construct while the career adaptability variables explain $74 \%$ of the variance. The hardiness variables (commitment and control) showed an inverse relationship with, and contributed the least in explaining the variance $(8 \%)$ in the psychological career meta-capacities construct.

\section{Discussion}

Overall, the results suggested that the psychological career meta-capacities (self/other skills, behavioral adaptability, career directedness, curiosity, concern, control, confidence, curiosity, hardy-commitment and hardy-control) significantly contributed to explaining the participants' sense of fit with their work group, job and organization.

Several implications follow from the findings. First, increasing the participants' psychological career meta-capacities (psychological career resources and career adaptability resources) may assist them in managing or negotiating their personal fit with the work group, job or organization as an aspect of their careers. Psychological meta-capacities might influence other career or work-related outcomes such as job tenure and organizational commitment impacting the retention of valuable and talented staff. Employees who feel strongly embedded and committed may define their relationships with their employers as long term, and have lower intent to quit as opposed to employees who have lower levels of embeddedness and commitment to their organizations (Mallol et al., 2007).

The findings indicated that the participants' behavioral adaptability, self-management and interpersonal skills, and clarity about their future career direction were important to increase their job embeddness and organization commitment. Moreover, their overall career adaptability was also significantly related to their sense of fit with the job and organization. According to Mitchell et al. (2001a, 2001b), a fit between employees' values, career goals and plans for the future and the larger corporate culture as well as the demands of the immediate job (e.g., job knowledge, skills and abilities) leads to a stronger sense of embeddedness. Research by Van Dyk (2012) showed employees' satisfaction with career opportunities and the characteristics of their jobs (autonomy, skill variety and challenge) to be significantly related to their sense of job embeddedness (fit and sacrifice). Joâo (2010) also found the need for career growth and advancement opportunities and challenging work to be significant factors that keep professionally qualified employees from leaving their organizations.

More specifically, organizational career development support interventions should focus on developing the psychological career meta-capacities pointed out in the findings of the current study as important psychosocial resources to increase the participants' sense of job embeddedness (fit). Developing employees' career adaptability resources encourage proactive career behaviors which will help them to shape the problem-solving strategies and coping behaviors they need to synthesize their vocational self-concepts with their work-roles (Savickas, 2005) in negotiating the person-environment fit harmonics (Savickas \& Porfeli, 2012), thus increasing their attachment (sense of job-embedded fit) to the organization.

\section{Limitations and Future Research}

Since the present study has been limited to early career participants predominantly employed in the human resources management field in the South African organizational context, the findings cannot be generalized to other occupational contexts, age, race or gender groups. Furthermore, given the cross-sectional nature of the research design, this study can yield no statements about causation. Associations between the variables have therefore been interpreted rather than established. These findings therefore need to be replicated with broader samples across various occupational groups and economic sectors before more comprehensive conclusions can be drawn about the relationship between employees' psychological career meta-capacities (psychological career resources, career adaptability and hardiness) and their retention-related dispositions (job embeddedness and organizational commitment). Longitudinal studies are also recommended to investigate the relationship between these variables and how they influence the retention of employees over the long term.

\section{Conclusion}

From the findings of our study it can be concluded that developing and enhancing employees' psychological career 


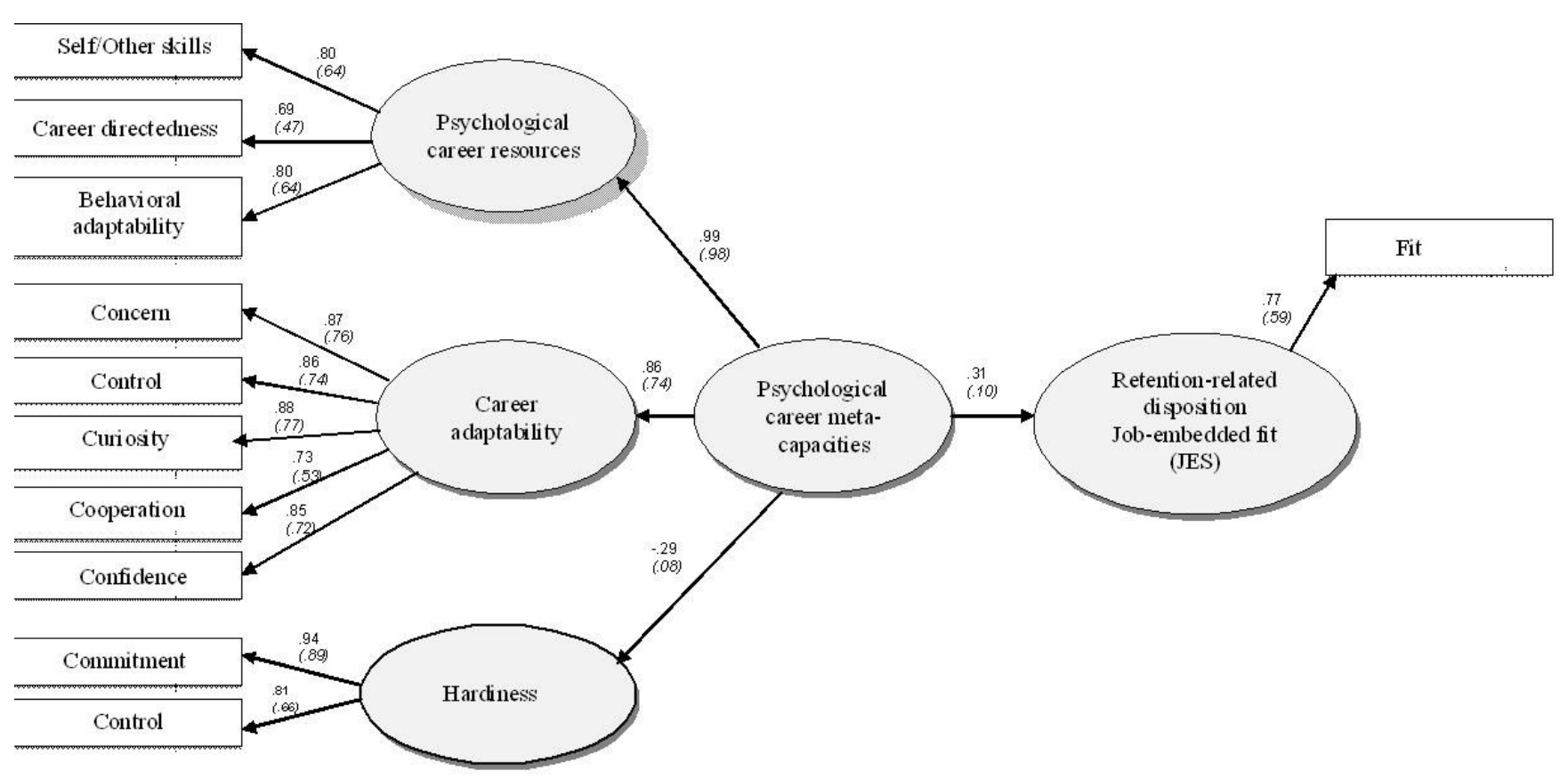

Figure 1. Final Structural model (3) linking the psychological career meta-capacities construct variables to the retention-related dispositions construct variable job-embedded fit. Note: All standardized path cooefficent estimates ${ }^{* * *} p=.001$. Squared multiole correlations (R2) shown in brackets

meta-capacities may assist them in managing or negotiating their personal fit with the work group, job or organization as an aspect of their careers. Should individuals perceive a low fit with the job or organization, they might have the confidence and inner drive or motivation (hardiness) to attempt to deal responsibly with the undesirable situation. They might draw on their career resources to deal positively with the perceived lack of fit. Organizational commitment appears to be less important than individuals' job-embedded fit in terms of retaining them. Managers and industrial psychologists may use the findings of the study to better understand the psychological factors that influence the retention of valuable staff members.

\section{References}

Allen, D. (2006). Do organisational socialisation tactics influence newcomer embeddedness and turnover? Journal of Management, 32, 237-256.

Allen, N., \& Meyer, J. (1990). The measurement and antecedents of affective, continuance and normative commitment to the organisation. Journal of Occupational Psychology, 63, $1-18$.

Arbuckle, J. L. (1995-2009). Amos 18 user's guide. Crawfordville, FL: Amos Development Corporation.

Arthur, M., Khapova, S., \& Wilderom, C. (2005). Career success in a boudaryless career world. Journal of Organizational Behavior, 26, 177-202.

Azeem, S. (2010). Personality hardiness, job involvement and job burnout among teachers. International Journal of Vocational and Technical Education, 2(3), 36-40.

Baruch, Y. (2004). Managing Careers. Harlow, England: Pearson Education.
Bezuidenhout, M. (2010). The development of an instrument to measure employability of students: A pilot study. Unpublished draft research proposal, Department of Human Resourse Management, University of Pretoria.

Briscoe, J. P., Hall, D. T., \& DeMuth, R. L. F. (2006). Protean and boundaryless careers: An empirical exploration. Journal of Vocational Behavior, 69, 3047.

Brown, C., George-Curran, R., \& Smith, M. (2003). The role of emotional intelligence in the career commitment and decision-making process. Journal of Career Assessment, 11(4), 379-392.

Carr, J., Kelley, B., Keaton, R., \& Albrecht, C. (2011). Getting to grips with stress in the workplace. Human Resource Management International Digest, 19(4), 32-38.

Coetzee, M. (2008). Psychological career resources and subjective work experiences of working adults: An South African survey. South African Journal of Industrial Psychology, 34(2), 32-41.

Coetzee, M., \& Bergh, Z. (2009). Psychological career resources and subjective work experiences of working adults: An exploratory study. SA Business Review, 13(2), 1-31.

Cohen, J. (1992). Quantitative methods in psychology: A power primer. Psychological Bulletin, 112(1), 153-159.

Delahaij, R., Gaillard, A., \& Van Dam, K. (2010). Hardiness and the response to stressful situations: Investigating mediating processes. Journal of Personality and Individual Differences, 49, 386-390.

Döckel, A., Basson, J. S., \& Coetzee, M. (2006). The effect of retention factors on organizational commitment: An investigation of high technology employees. South African Journal of Human Resource Management, 4(2), 20-28. 
Ebberwein, C., Krieskok, T., Ulven, J., \& Prosser, E. (2004). Voices in transition: Lessons on career adaptability. The Career Development Quarterly, 52, 292-308.

Feldman, D., \& Ng, T. (2007). Careers: Mobility, embeddedness, and success. Journal of Management, 33(3), 350-377.

Ferreira, N. (2009). The relationship between psychological career resources and organisational commitment. (Unpublished master's dissertation). University of Pretoria. Pretoria, South Africa.

Ferreira, N. (2012). Constructing a psychoogical career profile for staff retention (Unpublished doctoral thesis). University of South Africa, Pretoria.

Ferreira, N., Basson, J., \& Coetzee, M. (2010). Psychological career resources in relation to organisational commitment: An exploratory study. South African Journal of Human Resource Management, 8(1), 1-9.

Garson, G. (2008). Structural Equation Modeling: Statnotes, PA765. Retrieved 8 Feb 2012, from http://faculty.chass. ncsu.edu/garson/PA765/structur.html

Griffeth, R.W., Hom, P.W., \& Gaertner, S. (2000). A meta-analysis of antecedents and correlates of employee turnover: Update, moderator tests, and research implications for the millenium. Journal of Management, 256, 463-488.

Hair, J., Black, W., Babin, B., \& Anderson, R. (2010). Multivariate data analysis. Pearson, NJ: Pearson Education.

Halbesleben, J. R. B., \& Wheeler, A. R. (2008). The relative roles of engagement and embeddedness in predicting job performance and intention to leave. Work \& Stress, 22(3), 242-256.

Hausknecht, J., Rodda, J., \& Howard, M. (2009). Targeted employee retention: Performance based and job-related differences in reported reasons for staying. Human Resource Management, 48(2), 269-288.

Hom, P. W., \& Griffeth, R. W. (1995). Employee turnover. Cincinnati, $\mathrm{OH}$ : South-Western.

Hystad, S., Eid, J., Laberg, J., \& Johnsen, \& Bartone, P. (2010). Academic stress and health: Exploring the moderating role of personality hardiness. Scandinavian Journal of Educational Research, 53, 421-429.

Joâo, T. F. (2010). The relationship between perceived career mobility, career mobility preference, job satisfaction and organisational commitment (Unpublished master's dissertation). University of South Africa, Pretoria.

Kidd, J. (2008). Exploring components of career well-being and the emotions associated with significant career experiences. Journal of Career Development, 35(2), 166-186.

Kniveton, B. (2004). Managerial career anchors in a changing business environment. Journal of European Industrial Training, 28(7), 564-573.

Kobasa, S. (1982). The hardy personality: Toward a social psychology of stress and health. In G. S. Sanders \& J. Suls (Eds.), Social psychology of health and illness. Hillsdale, $\mathrm{NJ}$ : Lawrence Erlbaum.

Kobasa, S. (1987). Stress responses and personality. In R. C. Barnette \& L. Biener (Eds.), Gender and stress. New York, NY: The Free Press.

Kobasa, S., Maddi, S., \& Kahn, S. (1982). Hardiness and health: A prospective study. Journal of Personality and Social Psychology, 42, 168-177.
Kobasa, S., Maddi, S., \& Zola, M. (1985). Type A and hardiness. Journal of Behavioural Medicine, 6(1), 41-51.

Lee, T., Mitchell, T., Sablynski, C., Burton, J., \& Holtom, B. (2004). The effects of job embeddedness on organisational citizenship, job performance, volitional absences, and voluntary turnover. Academy of Management Journal, 47(5), 711-722.

Lumley, E. (2010). The relationship between career anchors, job satisfaction and organisational commitment. (Unpublished master's dissertation). University of South Africa, Pretoria.

Lumley, E., Coetzee, M., Tladinyane, E., \& Ferreira, N. (2011). Exploring the job satisfaction and organisational commitment of employees in the information technology environment. Southern African Business Review, 15(1), 100-118.

Maddi, S. (1987). Hardiness training at Illinois Bell Telephone. In J. P. Opatz (Ed.), Health promotion evaluation: Measuring the organizational impact (pp. 101-115). Stevens Point, WI: National Wellness institute.

Maddi, S. (2002). The story of hardiness: Twenty years of theorizing, research, and practice. Consulting Psychology Journal: Practice and Research, 54(3), 175-185.

Maddi, S., \& Khoshaba, D. (2005). Resilience at work. New York, NY: Amacom.

Maddi, S., \& Kobasa, S. (1984). The hardy executive: Health under stress. Chicago, IL: Dorsey Professional Books.

Maddi, S., Khoshaba, D., \& Pammenter, A. (1999). The hardy organisation: Success by turning changeto advantage. Consulting Psychology Journal, 51(2), 117-124.

Maddi, S., Khoshaba, D., Persico, M., Lu, J., Harvey, R., \& Bleecker, F. (2002). The personality construct of hardiness II: relationships with comprehensive tests of personality and psychopathology. Journal of Research in Personality, 36, 72-85.

Mallol, C., Holtom, B., \& Lee, T. (2007). Job embeddedness in a culturally diverse environment. Journal of Business Psychology, 22, 35-44.

Meyer, J., \& Allen, N. (1991). A three component conceptualization of organisational commitment. Human Resource Management Review, 1, 61-89.

Meyer, J., \& Allen, N. (1997). Commitment in the workplace, theory, research and application. Thousand Oaks, CA: Sage.

Mitchell, T., Holtom, B., \& Lee, T. (2001a). How to keep your best employees: The development of an effective retention policy. Academy of Management Executive, 15(4), 96-108.

Mitchell, T., Holtom, B., Lee, T., Sablynski, C. \& Erez, M. (2001b). Why people stay: Using job embeddedness to predict voluntary turnover. Academy of Management Journal, 44(6), 1102-1121.

Ng, E. S. W., \& Burke, R. J. (2005). Person-organisation fit and the war for talent: Does diversity management make a difference? International Journal of Human Resource Management, 16(7), 1195-1210.

Presti, A. L., Nonnis, M., \& Briscoe, J. P. (2011). The protean and boundaryless career in Italy: Game on? In M. Cortini, G. Tanucci, \& E. Morin (Eds.), Boundaryless careers and occupational well-being (pp. 7-16). New York, NY: Palgrave McMillan. 
Rappaport, A., Bancroft, E., \& Okum, L. (2003). The aging workforce raises new talent management issues for employers. Journal of Organizational Excellence, 23, 55-66.

Rossier, J., Zecca, G., Stauffer, S.D., Maggiori, \& Dauwalder, J. (2012). Career Adapt-Abilities Scale in a French-speaking Swiss sample: Psychometric properies and relatinships to personality and work engagement. Journal of Vocational Behavior, 80, 734-743.

Samuel, M., \& Chipunza, C. (2009). Employee retention and turnover: Using motivational variables as a panacea. African Journal of Business Management, 3(8), 410-415.

Savickas, M. (1997). Career adaptability: An integrative construct for life-span, life-space theory. Career Development Quarterly, 45(3), 247-259.

Savickas, M. (2005). The theory and practice of career construction. In S. D. Brown \& R. W. Lent (Eds.), Career development and counselling: Putting theory and research to work. Canada: John Wiley.

Savickas, M. (2010). The Career Adapt-Abilities Inventory. Personal documentation received from author at the 27th International Congress of Applied Psychology (ICAP), 11-16 July, Melbourne, Australia.

Savickas, M .L. (2011). New questions for vocational psychology: Premises, paradigms, and practices. Journal of Career Assessment, 19(3), 251-258.

Savickas, M. L., Nota, L., Rossier, J., Dauwalder, J. P., Duarte, M. E., \& Guichard, J.. (2009). Life designing: A paradigm for career construction in the 21st century. Journal of Vocational Behavior, 75, 239-250. doi: 10.1016/j.jvb.2009.04.004.

Savickas, M. L., \& Porfeli, E. J. (2012). Career Adapt-Abilities Scale: Construction, reliability, and measurement equivalence across 13 countries. Journal of Vocational Behavior, 80, 661-673.

Schein, E. (1996). Career anchors revisited. Implications for career development in the 21st century. Academy of Management Executive, 1, 80-88.

Shaw, J. D., Delery, J. E., Jenkins, G. D., \& Gupta, N. (1998). An organization-level analysis of voluntary and involuntary turnover. Academy of Management Journal, 41, 511-525.

Sullivan, S. E. \& Arthur, M. B. (2006). The evolution of the boundaryless career concept: examining physical and psychological mobility. Journal of Vocational Behavior, 69(1), 19-29.

Tanova, C., \& Holtom, B.C. (2008). Using job embeddedness factors to explain voluntary turnover in four European countries. The International Journal of Human Resource Management, 19(9), 1553-1568.

Van Dam, K. (2004). Antecedence and consequences of employability orientation. European Journal of Work and Organisational Psychology, 13(1), 29-51.

Van Dyk, J. (2012). SEQ CHAPTER $\backslash h \backslash r 1$ The relationship between organisational commitment, retention factors and job embeddedness (Unpublished master's dissertation). University of South Africa, Pretoria.

Zhang, L. (2010). Hardiness and the Big five personality traits among Chinese university students. Journal of Learning and Individual Differences, 1, 1-5. 